L. Radchenko, Cand. Sc. (Law), Associate Prof.

Taras Shevchenko National University of Kyiv, Kyiv, Ukraine

\title{
LEGAL REGULATION OF DIVORCE: HISTORICAL DEVELOPMENT AND MODERN PRINCIPLES
}

The article is devoted to the study of the genesis of legal regulation of the order, conditions and consequences of divorce in its historical aspect, as well as given the current principles of family relations in EU law and foreign law, highlighting the latest trends in divorce relations and outlining the laws of their further consolidation in the family law of Ukraine, formulation of conclusions and proposals aimed at harmonization of national legislation with EU law.

The divorce procedure, its conditions and legal consequences are regulated by the legislation of different states in different ways. The regulation of divorce relations is also significantly influenced by national characteristics, traditions, religion and culture. The spread of family relations outside one state necessitates the application of foreign law to regulate such relations. Appropriate conflicts may result from the application of the law of different states regarding the grounds for divorce, the procedure for divorce, as well as the unequal determination of the moment of its dissolution.

The article argues that one of the basic principles of Roman private law was the observance of absolute freedom of divorce. However, during the imperial period, and especially with the establishment of Christianity, restrictions were imposed on divorce.

The approach to significant restrictions and even prohibitions on divorce has long been observed in the law of European states. Under the influence of the Catholic Church and Christian morality, the recipient law did not allow divorce at all or established restrictions and valid grounds for divorce. Divorce was allowed only as an exception, in the presence of significant circumstances, subject to complicated procedures.

Since the second half of the twentieth century, divorce laws have been reformed in many countries, tending to abandon the idea that divorce is a sanction for marital misconduct and moving to the concept that divorce is a statement of a failed marriage. As a result of the reforms, divorces have become more liberalized.

The article concludes that the general conflict principle of divorce is the law of citizenship of a spouse or husband (most countries of continental Europe) or the law of the place of residence of the spouses (England, USA and a number of other countries). However, Regulation 1259/2010 provides, in essence, innovative provisions for the choice of the competent legal order in the event of divorce, which enshrines the possibility for spouses to independently choose the applicable law.

Keywords: marriage, marital relations, divorce, termination of marriage, EU law, family law.

Bulletin of Taras Shevchenko National University of Kyiv.

Legal Studies, 2021; 3 (118): 122-127

УДК 347.98

DOI: https:doi.org/10.17721/1728-2195/2021/3.118-22
ISSN $1728-2195$

(c) Taras Shevchenko National University of Kyiv, Publishing center "Kyiv University", 2021

О. 3. Хотинська-Нор, д-р юрид. наук, зав. каф. Київський національний університет імені Тараса Шевченка, Київ, Україна ORCID ID: 0000-0002-4480-6677

\section{"БЕЗСТОРОННІСТЬ СУДУ" ЯК СТАНДАРТ СПРАВЕДЛИВОГО ПРАВОСУДДЯ: ПРАКТИКА ЄСПЛ I ПЕРСПЕКТИВИ РОЗВИТКУ В УКРАЇНІ}

Досліджено зміст і природу такого усталеного стандарту справедливого правосуддя як безсторонність суду, що широко витлумачений у практиці Єөропейського суду з прав людини. На підставі системного аналізу масиву рішень єСПЛ виокремлено суттєві позиції, що характеризують стандарт безсторонності суду. До них належать такі: 1) безсторонність суду перебуває у дихотомічному зв'язку з категорією "упередженість"; 2) безсторонність суду оцінюється за двома критеріями: (а) суб'єктивним, який перебуває у "площині" особистості судді та його переконань; (б) об'єктивним, який перебуває у "площині" існуючих гарантій і механізмів, якими повинен скористатися суд, щоб уникнути обгрунтованих сумнівів у необ'єктивності та звинувачень в упередженості на свою адресу; 3) визначальний вплив зовнішнього прояву безсторонності суду; 4) раціональна обґрунтованість сумнівів у безсторонності; 5) різноманітність і необмежене коло ситуацій, що можуть породити сумніви у безсторонності суду.

Ураховуючи, що ЄСПЛ оцінює безсторонність національного суду за суб'єктивним і об'єктивним критеріями, їм приділено особливу увагу та визначено специфіку застосування. У процесі аналізу зроблено висновок, що поява таких критеріїв обумовлена складною етико-правовою природою досліджуваного стандарту. Обґрунтовано, що стандарт безсторонності суду сягає своїм корінням моральної основи суддівської професії, що еволющіонувала та трансформувалася у систему правил професійної поведінки та норм законодавства, спрямованих на досягнення мети судочинства та реалізацію особою права на справедливий суд. Етична природа безсторонності суду зумовлює оцінку відповідності цьому стандарту за суб'єктивним показником. Водночас її правова природа, яка охоплює інституціональну та процесуальну складові, спонукає до розвитку в національному законодавстві відповідних гарантій, існування яких є критерієм оцінки безсторонності суду за об'єктивним критерієм. У контексті останньої тези наголошено на особливому значенні інституту відводу (самовідводу) судді як процесуальній гарантії безсторонності суду. Аргументовано, що в національному цивільному, господарському й адміністративному судочинстві правила та порядок відводу судді потребують удосконалення в напрямку реалізації постулату "ніхто не може бути суддею у власній справі".

Ключові слова: безсторонність суду, неупередженість суду, незалежність суду, справедливе правосуддя, право на справедливий суд, критерії оцінки безсторонності суду, стандарти правосуддя.

\section{ВСТУП}

2021 року Україна відзначає 30 років своєї незалежності, 30 років із дня, коли український народ узяв відповідальність за власну долю та розвиток власної нації та держави. Обравши курс на побудову демократичної, правової, соціальної держави, в якій людина є основною цінністю та сповідується принцип верховенства права, Україна стала на складний і тернистий шлях трансформації. Цей шлях характеризується своєю специффікою, зумовленою історичним корінням і традиціями, геополітичним розташуванням і економічною нестабільністю, необхідністю поступової еволюції правової свідомості та культури громадян.

Одним із нагальних питань на шляху розбудови нашої держави, яке всі 30 років її незалежності не втрачає своєї актуальності, є питання організації незалежної судової влади, ефективне функціонування якої $€$ ядром правової держави та необхідним інструментом у механізмі забезпечення верховенства права. Її сучасна модель склалася під впливом різних чинників, визначальним серед яких стала ратифікація Україною 1997 року Конвенції про захист прав людини й основоположних свобод, а разом із нею - визнання юрисдикції Європейського суду з прав людини. Це сприяло якісно новому підходу до розуміння соціально-правової природи та соціального призначення інституту правосуддя, спонукаючи до різного роду кроків на шляху реформування судової влади України задля втілення міжнародних стандартів справедливого правосуддя в державі. Система останніх передбачає складну структуру, множинність вимог, які стосу- 
ються інституційного (структурного) компонента (організація судового устрою) та процесуального компонента (судочинство), що змістовно еволюціонують під впливом суспільного розвитку. Однак серед їх числа традиційно виокремлюють базові стандарти, відповідність яким визначає характеристику та стан національної системи судового захисту, правосуддя. Одним із таких є стандарт безстороннього суду, який розглядають як інституційну гарантію права на справедливий суд, що перебуває у нерозривному зв'язку з процесуальним режимом.

Як стандарт, безсторонність суду набула широкого тлумачення у практиці ЄСПЛ, використовується національними судами для мотивації судових рішень і дискутується у наукових публікаціях. Однак з огляду на нестабільність вітчизняного законодавства та перманентність судових реформ, його дослідження не втрачає актуальності, оскільки говорити про його абсолютне втілення у національній правовій системі не доводиться.

У цій статті ми маємо на меті проаналізувати усталені у практиці ЄСПЛ елементи стандарту "безсторонність суду" та дослідити його природу, оцінивши його щодо перспективи розвитку у національному законодавстві.

Щоб досягти заявленої мети ми використаємо діалектичний метод наукового пізнання, що дозволить дослідити сутність стандарту безстороннього суду, а також логіко-структурний і аналітичний методи, які забезпечать демонстрацію взаємозв'язку складної, багатокомпонентної природи досліджуваного стандарту 3 критеріями його оцінки, сформованими ЄСПЛ.

\section{ОСНОВНІ РЕЗУЛЬТАТИ}

"Безсторонність суду": критерії оцінки у практиці єспЛ. Слід констатувати, що українське процесуальне законодавство замість слова "безсторонність" використовує синонімічний за змістом термін "неупередженість" (судового розгляду, вирішення спорів/справ) (ст. 2 ЦПК України, ст. 2 ГПК України, ст. 2 КАС України, ст. 2 КПК України). Проте визначення "неупередженості" ("безсторонності") суду законодавство не містить, тому в питанні тлумачення та застосування цього поняття національні суди звертаються безпосередньо до практики ЄСПЛ, масив якої сьогодні в цьому аспекті доволі значний.

Так, ЄСПЛ стоїть на позиції, що "безсторонність", як правило, означає відсутність упередженості або необ'єктивності, а її існування або відсутність можуть встановлюватися різними шляхами. "Відповідно до усталеної практики Суду існування безсторонності для цілей п. 1 ст. 6 повинно встановлюватися згідно з: (i) суб'єктивним критерієм, при якому мають ураховуватись особисті переконання та поведінка конкретного судді (тобто, чи мав суддя будь-які особисті упередження або чи був він об'єктивним у цій справі); та (ii) об'єктивним критерієм, тобто шляхом установлення того, чи забезпечував сам суд (та, серед інших аспектів, його склад) достатні гарантії для того, щоб виключити будь-який обґрунтований сумнів у його безсторонності (див., наприклад, рішення у справі "Моріс проти Франції" [ВП] (Morice v. France) [GC], заява № 29369/10, п. 73, ЄСПЛ 2015, 3 подальшими посиланнями). У контексті об'єктивного критерію, крім поведінки судді, слід визначити, чи існують переконливі фракти, які можуть викликати сумніви щодо його або її безсторонності. Це означає, що при вирішенні того, чи $є$ у відповідній справі обґрунтована причина побоюватися, що конкретний суддя або орган, який засідає в якості суду, є небезстороннім, позиція заінтересованої особи є важливою, але не вирішальною. Вирішальним $€$ те, чи можна вважати таке побоювання об'єктивно обґрунтованим (там само, п. 76). Об'єктивний критерій в основному стосується ієрархічних чи інших зв'язків між суддею й іншими учасниками провадження. У зв'язку із цим навіть зовнішні прояви мають певну важливість, або, іншими словами, "правосуддя має не лише здійснюватися, має бути видно, що воно здійснюється". Адже йдеться про довіру, яку в демократичному суспільстві суди повинні вселяти у громадськість" (справа "Михайлова проти України") [1].

Наведена позиція $є$ тривалою й усталеною і вказує на вагомі у процесі оцінки безсторонності суду вихідні позиції:

1) безсторонність суду перебуває у дихотомічному зв'язку з категорією "упередженість". В ії оцінках ЄСПЛ бере до уваги: (а) чи надавались суддею переваги одній із сторін спору; (б) чи мала місце дискримінація суддею однієї зі сторін спору;

2) безсторонність суду оцінюється за двома критеріями: (а) суб'єктивним, який міститься у "площині" особистості судді та його переконань; (б) об'єктивним, який перебуває у "площині" існуючих гарантій і механізмів, якими повинен скористатися суд, щоб уникнути обґрунтованих сумнівів у необ'єктивності та звинувачень в упередженості на свою адресу.

Перевірка на суб'єктивну безсторонність полягає у з'ясуванні особистих переконань і мотивів, якими керувався суд у конкретній справі, що на практиці $€$ доволі ускладненим завданням. "Суд далі нагадує, що "безсторонність", у сенсі п. 1 ст. 6, має визначатися відповідно до суб'єктивного критерію, на підставі особистих переконань і поведінки конкретного судді у конкретній справі - тобто, жоден із членів суду не має проявляти будь-якої особистої прихильності або упередження..." (справа "Бочан проти України") [2]

При визначенні безсторонності суду за суб'єктивним критерієм у ЄСПЛ керуються презумпцією добросовісності судді, яка відома нам із римської сентенції bona fides simper praesumitur, nisi malam fidem adesse probetur. Тобто суддя вважається безстороннім, якщо відсутні докази, які б свідчили про протилежне. "Стосовно суб'єктивного критерію, особиста безсторонність суду презюмується, поки не надано доказів протилежного" (справа "Білуха проти України) [3].

У зв'язку з труднощами, пов'язаними з необхідним ступенем доказовості, які виникають в оцінці безсторонності суду за суб'єктивним критерієм, ЄСПЛ приділяє особливу увагу об'єктивному критерію, який вимагає визначити наявність у суду достатніх гарантій, які б виключали обґрунтовані сумніви у безсторонності. "У контексті об'єктивного критерію у цій справі окремо від поведінки суддів слід визначити, чи існували переконливі фракти, які могли б викликати сумніви щодо їхньої безсторонності. Це означає, що у разі вирішення того, чи є у цій справі обґрунтовані причини побоюватися, що певний суддя був небезстороннім, позиція заінтересованої особи $є$ важливою, але не вирішальною. Вирішальним $є$ те, чи можна вважати такі побоювання об'єктивно обґрунтованими" (справа "Газета "Україна-Центр" проти України) [4].

Проте ЄСПЛ використовує об'єктивний критерій, який передбачає оцінку фрактів, які можна перевірити, як додаткову гарантію, зокрема у випадку, коли суб'єктивний критерій не дозволяє з'ясувати, що особисті переконання судді призвели до його упередженості (справа "Філюткін проти Росії" [5]).

На відміну від суб'єктивного критерію, за яким безсторонність суду презюмується, в її оцінці за об'єктивним критерієм ЄСПЛ, навпаки, бере до уваги, чи було докладено з боку національних органів зусиль, щоб переконати учасників процесу у безсторонності суду: суд повинен "заспокоїти" сумніви сторони в цьому питанні (справа "Ванєєв проти Росії [6]). "Тим не менш: суддя має переконати раціональну людину поза розум- 
ним сумнівом. Тобто, учаснику справи достатньо сумнівів "на перший погляд", тоді як суд має доказати неупередженість "поза розумним сумнівом" [7]. Іншими словами, хоча безсторонність суду презюмується, у разі виникнення сумнівів щодо неї, тягар доказування покладається на суд: він повинен довести, що сумніви $є$ безпідставними та раціонально необґрунтованими.

Попри диференціацію критеріїв оцінки безсторонності суду, вони перебувають у тісному взаємозв'язку та не можуть цілковито розмежовуватися, "оскільки поведінка судді не тільки може викликати об'єктивні побоювання щодо його безсторонності з погляду стороннього спостерігача (об'єктивний критерій), а також може бути пов'язана з питанням його або її особистих переконань (суб'єктивний критерій) (рішення у справі Кіпріану проти Кіпру) (постанова Верховного Суду від 02.12.2020 р. у справі № 2-5229/09 [8]). Тому у застосуванні критеріїв оцінки безсторонності суду, розстановці щодо них акцентів, значення мають обставини конкретної справи;

3) акцент на об'єктивний критерій у практиці ЄСПЛ обумовив появу та розвиток доктрини "зовнішніх проявів", яка у численних рішеннях ЄСПЛ втілена завдяки такому формулюванню: "У межах об'єктивної оцінки має бути визначено, чи наявні факти, що можуть бути перевірені, які породжують сумніви щодо неупередженості судів. У цьому зв'язку навіть зовнішні ознаки мають певне значення. Вирішується питання довіри, яку суди в демократичному суспільстві мають вселяти суспільству і, перш за все, сторонам у процесі" (наприклад, справа "Салов проти України") [9].

Зовнішній прояв безсторонності суду має визначальний вплив, оскільки ЄСПЛ пов'язує й обґрунтовує неупередженість суду з довірою, джерелом якої повинен бути суд у демократичному суспільстві. "Головне не те, що робить і чого не робить суддя, а те, що, на думку інших, суддя зробив або може зробити" [10].

У цьому сенсі показовою $є$ справа "Паскал проти України", в якій ЄСПЛ висловив сумнів щодо безсторонності національного суду, оскільки у перші тижні судового розгляду у газеті було опубліковано інтерв'ю судді про винуватість заявника. Хоча суддя намагалась дистанціюватись і заперечувала, що будь-коли давала інтерв'ю цій газеті, вимагаючи втручання прокуратури, однак ефективне розслідування та з'ясування обставин публікації проведено не було, а тому, на думку ЄСПЛ, "не було усунуто ознак небезсторонності судді" [11]. Тобто, в оцінці, чи був національний суд безстороннім, ЄСПЛ відштовхувався від того, який ефект, зовнішнє враження створило опубліковане інтерв'ю з позиції стороннього спостерігача. Заперечення суддею свого авторства публікації не було переконливим з огляду на відсутність ефективного розслідування за зверненням судді. Відтак, на думку ЄСПЛ, судом не було забезпечено власної об'єктивності при розгляді справи;

4) "позиція заінтересованої особи є важливою, але не вирішальною". У питанні оцінки безсторонності суду за об'єктивним критерієм сумніви заявника мають значення, проте визначальним $€$ те, чи можна вважати такі сумніви об'єктивно обґрунтованими. Іншими словами, сумніви у безсторонності суду мають бути не лише у сторони судового процесу, а й видаватися розумними сторонньому спостерігачу, оскільки фактично вони можуть бути необґрунтованими. "Сумніви повинні ґрунтуватися на фрактичних обставинах; не припустимими $є$ гіпотези про можливий розвиток подій" (справа "Булут проти Австрії) [12];

5) сумніви у безсторонності суду можуть стосуватися різноманітних ситуацій, множинність яких обумовлена особливостями національного законодавства, особистими якостями судді, його зв'язками та поведінкою як у судовому процесу, так і поза ним. Саме ця множинність робить безперспективною спробу навести повний перелік причин, що можуть спричинити сумніви у безсторонності суду. Утім, як випливає з наведеної вище цитати рішення ЄСПЛ у справі "Михайлова проти України", найчастіше підозри в упередженості суду за об'єктивним критерієм криються в ієрархічних чи інших зв'язках між суддею й іншими учасниками провадження. У багатьох випадках ідеться про так звану "структурну" безсторонність, коли на різних етапах провадження особа виконувала різні за метою функції. Наприклад, коли суддя на попередній роботі виконував функцію обвинувача (справа "Пієрсак проти Бельгії") або брав участь у досудовому розслідуванні (справа "Де Куббер проти Бельгії"), або приймав рішення у попередній судовій інстанції (справа "Обершлік проти Австрії"). У контексті існування "структурної" безсторонності слід також розглядати ситуації, за яких сумніви породжуються внутрішніми зв'язками судової системи (справи "Газета "Україна-Центр" проти України", "Редакція газети "Гривна" проти України) чи зв'язками всередині суду (справи "Ванєєв проти Росії", "Мітров проти Македонії").

Щодо "інших зв'язків", то вони можуть стосуватися як приватного (інтимного) життя судді (справи "Хмельрж проти Чеської Республіки", "Озпінар проти Туреччини"), його сімейних чи родинних стосунків (Мікаллеф проти Мальти) чи профессійної комунікації.

У будь-якому випадку ті чи інші соціальні зв'язки судді, їхній вплив на його неупереджене ставлення до справи та ії учасників, можливо оцінити за об'єктивним критерієм в силу існування певних норм, приписів, гарантій, заборон. Водночас, суб'єктивний критерій криється в особистості судді, його цінностях і моральних установках, які визначають його здатність до критичного мислення й об'єктивної оцінки реальності, а також уміння розставляти пріоритети відповідно до обмежень, які на нього покладає його професійний статус.

Наведене свідчить про складну, багатокомпонентну природу стандарту "безсторонність суду", що вимагає звернутися до ії̈ дослідження.

Етична та правова природа стандарту "безсторонність суду". Хоч у своїх оцінках безсторонності суду ЄСПЛ надає перевагу об'єктивному критерію, оскільки оцінка суб'єктивного є ускладненою, вважаємо, що в питанні природи, джерела походження досліджуваного стандарту, саме останній є первісним і має першорядне значення.

Як стандарт, безсторонність суду першочергово має етичний характер і лежить у площині категорій і постулатів суддівської етики. Переважна більшість положень міжнародних і національних актів, які регламентують етичні правила поведінки судді, так чи інакше пов'язані з безсторонністю судді, її проявами у поведінці, пересторогами, обмеженнями, заборонами, гарантіями.

Бангалорські принципи поведінки суддів як документ, що встановлює стандарти етичної поведінки суддів, виокремлює такий показник і принцип, як неупередженість необхідну умову для належного виконання суддею своїх обов'язків, застосування якого вимагає, щоб суддя був вільний від будь-яких схильностей, упередженості чи забобонів; щоб його поведінка у процесі та поза ним сприяла підтримці та зростанню довіри суспільства до судових органів; щоб суддя обмежив себе у діях, які можуть позбавити його права здійснювати правосуддя [13].

Наведене відповідним чином інтерпретовано у Кодексі суддівської етики, затвердженому XI черговим з'їздом суддів України 22.02.2013 р.: "Суддя повинен виконувати обов'язки судді безсторонньо і неупереджено та утримуватися від поведінки, будь-яких дій або висловлювань, що можуть призвести до виникнення сумнівів у рівності... 
Неупереджений розгляд справи є основним обов'язком судді. .... Суддя повинен враховувати, що сімейні, соціальні взаємовідносини чи будь-які інші стосунки та втручання з боку органів державної влади не мають вплинути на поведінку судді чи ухвалення судових рішень" [14].

Зазначені етичні правила поведінки є лише прикладом і не вичерпують себе.

Деякі науковці наголошують на виключно етичній основі безсторонності. Наприклад, Н. В. Радутна зазначає, що "... безсторонність, як суто етична категорія, надає незалежності моральний зміст, покладаючи на суддю суб'єктивний обов'язок дотримуватися незалежності, не чекаючи, коли вона буде забезпечена" [15, с. 33].

У цьому $є$ сенс, оскільки безсторонність, перш за все, випливає з морально-ціннісних орієнтирів судді, його світогляду, мислення, здатності протистояти спокусам і різноманітним проявам впливу, його психологічних можливостей абстрагуватися від власних інтересів, особистих переконань, прихильностей, симпатій. Безсторонність - це здатність судді поводитися в судовому процесі та поза ним таким чином, щоб у жодної людини, "розумного спостерігача" не виникло сумніву в необ'єктивності судді, його упередженому ставленні.

Тому з позиції етики безсторонність $є$ обов'язковою рисою особистості судді, чеснотою, яка обов'язково має бути в арсеналі його особистих і професійних якостей.

Етична складова безсторонності суду охоплює і раціональну, і емоційну сторону свідомості судді. Хоча щодо ролі останньої в науці тривають дискусії, оскільки традиційно безсторонність зводиться до ratio, до інтелектуальної та вольової сфрери, виключаючи емоційну, яка є джерелом емпатії, симпатії, антипатії. Існує підхід, відповідно до якого емоції справляють негативний вплив на безсторонність суду (ірраціональний підхід) [16]. Водночас, за іншого (когнітивістського) підходу, емоції сприяють формуванню такого стану свідомості, за якого досягається максимальний ступінь безсторонності у процесі прийняття судового рішення [17].

Своєрідним проявом етичної основи безсторонності $€$ вагомий акцент на неї у змісті присяги, яку складає особа, призначена на посаду судді: "об'єктивно, безсторонньо, неупереджено, незалежно, справедливо та кваліфріковано здійснювати правосуддя..." (ст. 57 Закону України "Про судоустрій і статус суддів"). Адже історично присяга, перш за все, склалася як моральний, релігійний (а не правовий) акт. Сутність присяги полягає в офіційному зобов'язанні, яке бере на себе особа з нагоди вступу в особливий соціальний стан - стан суддів, що передбачає усвідомлення нею виняткової відповідальності у виконанні взятих на себе обов'язків. Присяга судді сьогодні поєднує в собі правові, морально-етичні, соціальні норми... [18, с. 230].

Як етичний стандарт безсторонність суду справляє обмежувальний вплив на поведінку судді, його спосіб життя, соціальні зв'язки, висловлювання. Останні особливо актуальні, оскільки стосуються реалізації суддею свого невід'ємного права на свободу висловлювань, що також гарантується Конвенцією про захист прав людини й основоположних свобод (ст. 10). Проте це право не $є$ абсолютним, оскільки одним із чинників, що його обмежує, є примат безсторонності суду. У своїх оцінках осіб чи подій, заявах, що можуть виражатися у формі процесуальних документів, виступах у 3Мl чи спілкуванні у соцмережах, судді повинні бути стриманими й обачними, демонструючи "необхідну відчуженість від особистих переконань" (справи "Філюткін проти Російської Федерації", "Девідсонс і Савінс проти Латвії", "Лавентс проти Латвії").

Як свідчить численна практика ЄСПЛ у питанні балансу права судді на свободу слова та його безсторон- ності, навіть у тих справах, де порушення п. 1 ст. 6 Конвенції не було встановлено, ЄСПЛ рекомендував суддям утримуватися від вираження своєї думки, зокрема у ЗМІ, щоб уникнути будь-яких сумнівів у неупередженості (справа "Хім і Прживечерський проти Польщі").

Правова основа стандарту безсторонності суду бере витоки 3 нормативної констатації права особи на "справедливе правосуддя", що у різних інтерпретаціях закріплено у міжнародному та національному законодавстві, і лежить у площині його інституціональних і процесуальних гарантій.

Основними інституціональними гарантіями виступають норми судоустрійного законодавства, які визначають порядок зайняття суддівської посади та звільнення судді з посади, професійні імунітети, запобіжники від зовнішнього тиску, належний рівень матеріального забезпечення тощо. Кожний зі згаданих сегментів $є$ приводом для окремих досліджень і тією чи іншою мірою в перспективі потребує удосконалення, оскільки виконує подвійну роль: як інституційна гарантія забезпечує не лише безсторонність, а й незалежність суду. У цьому сенсі ці дві категорії перебувають у тісному та нерозривному взаємозв'язку. За певних обставин справи ЄСПЛ відмічає, що концепції незалежності й об'єктивної безсторонності $€$ тісно пов'язаними, i їх важко відокремити, коли аргументи заявника щодо відсутності незалежності та неупередженості суду базуються на одних і тих самих фактичних обставинах (справа "Агрокомплекс проти України" [19]). Загалом же незалежність і безсторонність суду розглядаються як два окремі й різні показники, "що пов'язані як атрибути суддівської посади, які посилюють один одного. Незалежність - необхідна передумова неупередженості та її забезпечення. Суддя може бути незалежним, проте не бути неупередженим. Однак суддя, який не є незалежним, не може за визначенням бути неупередженим (на інституційній основі)" [10].

Основними ж процесуальними гарантіями безсторонності суду виступають процесуальні правила формування складу суду, порядок розподілу справ між суддями, порядок відводу та самовідводу суддів, правила поведінки учасників судового процесу, а також вимоги щодо належної мотивації судових рішень. Щодо них ЄСПЛ також неодноразово висловлювався, наголошуючи на важливості їхнього існування та реальності. Проте серед них особливе місце, значення та увагу відведено інституту відводу (самовідводу) судді. "...слід брати до уваги питання внутрішньої організації й існування національних процедур для забезпечення безсторонності, а саме правил, що регулюють відвід суддів. Такі правила виражають заінтересованість національного законодавця з приводу усунення всіх обґрунтованих сумнівів щодо неупередженості відповідного судді чи суду, та $є$ спробою забезпечити неупередженість шляхом усунення причин таких проблем. Окрім забезпечення відсутності фактичної упередженості, вони спрямовані на усунення будьякого прояву небезсторонності, і таким чином сприяють підвищенню довіри, яку суди мають вселяти громадськості у демократичному суспільстві. Таким чином, будьякий суддя, стосовно якого $є$ законні підстави для побоювань у відсутності неупередженості, повинен взяти самовідвід" (справа "Паунович проти Сербії) [20].

Слід зазначити, що на шляху розвитку процесуальних гарантій безсторонності суду, утвердженню цього стандарту в національній правовій системі зроблено чимало вагомих кроків, серед яких варто згадати запровадження автоматизованого розподілу судових справ (усунення людського фактора в питанні визначення складу суду для розгляду справи), а також вве- 
дення заборони щодо повторної участі судді у розгляді справи (справа "Романова проти України" [21]).

Однак в аналізованому аспекті ці заходи не можна назвати достатніми, оскільки вітчизняні судові процедури потребують подальшої модернізації, зокрема, у напрямі зміни порядку вирішення питання про відвід судді в цивільному, господарському та адміністративному судочинстві. Ураховуючи аксіому, що ніхто не може бути суддею у власній справі (nemo iudex in causa sua), нелогічною вбачається існуюча у зазначених видах судочинства ситуація, за якої питання про відвід загалом вирішується тим складом суду, якому його заявлено. Не дивно, що у багатьох випадках суд відмовляє у задоволенні заяви про відвід, адже протилежне означало б, що служитель Феміди визнає фракт наявної підстави для відводу (як наслідок - можливої упередженості), що повинно було б його, у першу чергу, спонукати до самовідводу, чого він, у свою чергу, не зробив, а отже, порушив закон. Саме тому, на нашу думку, необхідно, щоб питання про відвід судді (суду) вирішувалось іншим суддею (складом суду) цього ж суду, як це має місце у кримінальному провадженні і передбачено ст. 81 КПК України. Наведене дозволить також уніфрікувати процедуру відводу суду, що, крім іншого, сприятиме зрозумілості її для громадян, а отже, - доступності правосуддя.

Убачається, що запропонований підхід більше відповідатиме сформованій ЄСПЛ позиції, відповідно до якої, у випадку, коли має місце заява щодо сумнівів у неупередженості суду, національний судовий орган повинен ретельно перевірити, чи є цей склад суду "безстороннім судом" у розумінні ст. 6 Конвенції. I така перевірка має бути ефективною і здатною усунути сумніви стосовно реальності та характеру заявлених фактів (справа "Фархі проти Франції" [22]).

Як бачимо, стандарт безсторонності суду сягає своїм корінням моральної основи суддівської професії, що еволюціонувала та трансформувалася у систему правил професійної поведінки та норм законодавства, спрямованих на досягнення мети судочинства та реалізацію особою права на справедливий суд. Етична природа безсторонності суду зумовлює оцінку відповідності цьому стандарту за суб'єктивним показником (тестом). Водночас її правова природа, яка охоплює інституціональну та процесуальну складові, спонукає до розвитку в національному законодавстві відповідних гарантій, існування яких є критерієм оцінки безсторонності суду за об'єктивним критерієм (тестом).

\section{ВИСНОВКИ}

Проведений у межах цього дослідження вибірковий аналіз рішень ЄСПЛ, в яких прямо або опосередковано витлумачено стандарт "безсторонність суду", дозволяє зробити важливі для його змістовного розвитку висновки.

Основу стандарту "безсторонність суду" складає його етична та правова (інституціональна, процесуальна) природа. Саме вона зумовлює підхід, за якого оцінка національних практик на відповідність йому здійснюється за суб'єктивним (етична природа) і об'єктивним (правова природа) критеріями.

Суб'єктивний критерій $€$ визначальним, оскільки криється в особистості судді, його цінностях, моральних установках і ментально-емоційному стані, які здатні забезпечити необхідний рівень абстрагування від власних симпатій або антипатій і упередити прояв будь-яких прихильностей до учасників судового процесу чи заінтересованості у розгляді справи. Саме тому безсторонність суду за суб'єктивним критерієм, з одного боку, презюмується, а з іншого, ускладнює можливість її оцінювання. Останнє зумовлює особливу увагу ЄСПЛ до об'єктивного критерію, який вимагає визначити наявність у суду достатніх гарантій, які б виключали обґрунтовані сумніви у безсторонності.

Диференціація критеріїв оцінки безсторонності суду не призводить до їх цілковитого розмежування, оскільки вони $€$ взаємозалежними. Тому у застосуванні критеріїв оцінки безсторонності суду, розстановці щодо них акцентів, значення мають обставини конкретної справи.

Прискіплива увага ЄСПЛ до об'єктивного критерію оцінки безсторонності суду зумовила ряд особливостей його застосування: 1) субсидіарний характер (застосовується як додаткова гарантія, зокрема, у випадках, коли суб'єктивний критерій не дозволяє з'ясувати, що особисті переконання судді призвели до його упередженості); 2) тягар доказування безсторонності покладається на суд (чи було докладено з боку національних органів зусиль, щоб переконати учасників процесу у безсторонності суду: суд повинен "заспокоїти" їхні сумніви); 3) важливе значення "зовнішніх проявів" ("головне не те, що робить і чого не робить суддя, а те, що, на думку інших, суддя зробив або може зробити"); 4) сумніви у безсторонності суду мають бути об'єктивно обґрунтованими, а не базуватися на припущеннях.

Як етичний стандарт, безсторонність суду справляє обмежувальний вплив на реалізацію суддею окремих прав, поведінку судді, його спосіб життя, соціальні зв'язки, висловлювання тощо. Водночас його правова основа скеровує до його інституціональних і процесуальних гарантій, закріплених у національному законодавстві.

У контексті інституційних гарантій стандарт безсторонності суду тісно та нерозривно пов'язаний із незалежністю суду. Процесуальні гарантії безсторонності суду втілені у різних процесуальних інститутах, чільне місце серед яких відводиться інституту відводу (самовідводу) судді. У національному цивільному, господарському й адміністративному судочинстві правила та порядок відводу судді потребують удосконалення, ураховуючи сентенцію "ніхто не може бути суддею у власній справі", яка підкріплена відповідною практикою ЄСПЛ.

Список використаних джерел:

1. Case of Mikhaylova v Ukraine (Application № 10644/08) 06.03.2018. URL: https://hudoc.echr.coe.int/eng\#\{\%22fulltext\%22:[\%22 Mikhaylova\%20v.\%20Ukraine\%22],\%22documentcollectionid2\%22:[\%22GR ANDCHAMBER\%22,\%22CHAMBER\%22],\%22itemid\%22:[\%22001-191992\% 22]\} (дата звернення 01.08.2021)

2. Case of Bochan v. Ukraine (Application № 7577/02). 03.05.2007. URL: https://hudoc.echr.coe.int/eng\#\{\%22fulltext\%22:[\%22Bochan $\% 20 \mathrm{v} . \%$ 20Ukraine \%22],\%22documentcollectionid2\%22:[\%22GRANDCHAMBER\%2 2,\%22CHAMBER\%22],\%22itemid\%22:[\%22001-171916\%22]\} (дата звернення 01.08.2021).

3. Case of Belukha v. Ukraine (Application № 33949). 09.11.2006. URL: https://hudoc.echr.coe.int/eng\#\{\%22fulltext\%22:[\%22Belukha\%20v.\% 20Ukraine\%22],\%22documentcollectionid2\%22:[\%22GRANDCHAMBER\%2 2,\%22CHAMBER\%22],\%22itemid\%22:[\%22001-171904\%22]\} (дата звернення 01.08.2021)

4. Case of Gazeta Ukraina-Tsentr v. Ukraine (Application № 16695/04). 15.07.2010. URL: https://hudoc.echr.coe.int/eng\#\{\%22fulltext\%22:[\%22Gazeta \%20Ukraina-Tsentr\%22],\%22documentcollectionid2\%22:[\%22GRANDCHAMBER $\% 22, \% 22$ CHAMBER\%22],\%22itemid\%22:[\%22001-99854\%22]\} (дата звер нення 01.08.2021)

5. Case of Filyutkin v. Russia (Application № 39234/08). 24.07.2018. URL: https://hudoc.echr.coe.int/eng\#\{\%22itemid\%22:[\%22001-184813\%22]\} (дата звернення 01.08.2021).

6. Case of Vaneyev v. Russia (Application № 78168/13). 27.08.2019 URL: https://hudoc.echr.coe.int/eng\#\{\%22itemid\%22:[\%22001-195570\%22]\} (дата звернення 01.08.2021).

7. Laudan L. Is Reasonable Doubt Reasonable? Legal Theory. 2003. № 9(4). P. 295-331.

8. Постанова Верховного Суду від 02.12.2020 у справі № 2-5229/09. URL: https://reyestr.court.gov.ua/Review/93438176 (дата звернення 01.08.2021).

9. Case of Salov v. Ukraine (Application № 65518/01). 06.09.2005. URL: https://hudoc.echr.coe.int/eng\#\{\%22fulltext\%22:[\%22Salov\%20v.\%20 Ukraine \%22],\%22documentcollectionid2\%22:[\%22GRANDCHAMBER\%22,\% 22CHAMBER\%22],\%22itemid\%22:[\%22001-70096\%22]\} (дата звернення 01.08.2021).

10. Коментарі до Бангалорських принципів поведінки суддів. Управління ООН з наркотиків та злочинності. 2007. URL: http://rsu.gov.ua/ 
uploads/article/komentari-bangalorski-9818bfbb11.pdf (дата звернення 01.08.2021).

11. Case of Paskal v. Ukraine (Application № 24652/04). 15.09.2011. URL: https://hudoc.echr.coe.int/eng\#\{\%22fulltext\%22:[\%22Paskal\%20v.\%20 Ukraine\%22],\%22documentcollectionid2\%22:[\%22GRANDCHAMBER\%22,\% 22CHAMBER\%22],\%22itemid\%22:[\%22001-106169\%22]\} (дата звернення 01.08.2021).

12. Case of Bulut v. Austria (Application № 17358/90). 22.02.1996. URL: https://hudoc.echr.coe.int/eng\#\{\%22fulltext\%22:[\%22BULUT\%20v.\%20 AUSTRIA\%22],\%22documentcollectionid2\%22:[\%22GRANDCHAMBER\%22, \%22CHAMBER\%22],\%22itemid\%22:[\%22001-57971\%22]\} (дата звернення 01.08.2021)

13. Бангалорські принципи поведінки суддів. 19.05.2006. URL: https://zakon.rada.gov.ua/laws/show/995 j67\#Техt (дата звернення 01.08.2009).

14. Кодекс суддівської етики, затверджений XI черговим з'їздом суддів України. 22.02.2013. URL: https://zakon.rada.gov.ua/rada/show/ n0001415-13\#Text (дата звернення 01.08.2021)

15. Радутная Н.В. Этика судьи. М.: Российская академия правосудия, 2002. 212 с.

16. Fiss O.M. Reason in All Its Splendor. Brooklyn Law Review. 1991. № 56.

17. Tersman F. Intuitional Disagreement. The Southern Journal of Philosophy. 2012. № 50 .

18. Закон України "Про судоустрій і статус суддів". Науковопрактичний коментар / за заг. ред. М.А. Погорецького, О.З. ХотинськоїНор, О.Г. Яновської. Київ: Алерта, 2019. 668 с.

19. Case of Agrokompleks v. Ukraine (Application № 23465/03). 25.07.2013. URL: https://hudoc.echr.coe.int/eng\#\{\%22fulltext\%22:[\%22 Agrokompleks $\% 20 \mathrm{v} . \% 20$ Ukraine $\% 22], \% 22$ documentcollectionid2\%22:[\%22 GRANDCHAMBER\%22,\%22CHAMBER\%22],\%22itemid\%22:[\%22001-20

$7964 \% 22$ ]) (дата звернення 01.08.2021).

20. Case of Paunovic v. Serbia (Application № 54574/07). 03.12.2019. URL: https://hudoc.echr.coe.int/eng\#\{\%22itemid\%22:[\%22001-198991\%22]\} (дата звернення 01.08.2021).

21. Case of Romanova v. Ukraine (Application № 33089/02). 13.12.2007. URL: https://hudoc.echr.coe.int/eng\#\{\%22fulltext $\% 22:[\% 22$ Romanova\%20v.\%20Ukraine\%22],\%22documentcollectionid2\%22:[\%22GR ANDCHAMBER\%22,\%22CHAMBER\%22],\%22itemid\%22:[\%22001-

83969\%22]\} дата звернення 01.08.2021).

22. Case of Farhi v. France (Application № 17070/05). 16.01.2007. URL: https://hudoc.echr.coe.int/eng\#\{\%22fulltext\%22:[\%22Farhi\%22],\%22 documentcollectionid2\%22:[\%22GRANDCHAMBER $\% 22, \% 22$ CHAMBER $\% 2$ 2],\%22itemid\%22:[\%22001-79047\%22]\} (дата звернення 01.08.2021).

\section{References}

1. Case of Mikhaylova v. Ukraine (Application № 10644/08). 06.03.2018. https://hudoc.echr.coe.int/eng\#\{\%22fulltext\%22:[\%22Mikhaylova \%20v \%20Ukraine\%22] \%22documentcollectionid2\%22:[\%22GRANDCHAM BER\%22,\%22CHAMBER\%22],\%22itemid\%22:[\%22001-191992\%22]\}

2. Case of Bochan v. Ukraine (Application № 7577/02). 03.05.2007. https://hudoc.echr.coe.int/eng\#\{\%22fulltext\%22:[\%22Bochan\%20v.\%20Ukra ine \%22],\%22documentcollectionid2\%22:[\%22GRANDCHAMBER\%22,\%22 CHAMBER\%22],\%22itemid\%22:[\%22001-171916\%22]]

3. Case of Belukha v. Ukraine (Application № 33949). 09.11.2006. https://hudoc.echr.coe.int/eng\#\{\%22fulltext\%22:[\%22Belukha\%20v.\%20Ukr aine\%22] \%22documentcollectionid2\%22:[\%22GRANDCHAMBER\%22,\%22 CHAMBER\%22],\%22itemid\%22:[\%22001-171904\%22]\}
4. Case of Gazeta Ukraina-Tsentr v. Ukraine (Application № 16695/04). 15.07 2010. https://hudoc.echr.coe.int/eng\#\{\%22fulltext\%22:[\%22Gazeta\%20 Ukraina-Tsentr\%22],\%22documentcollectionid2\%22:[\%22GRANDCHAMBER $\% 22, \% 22$ CHAMBER\%22],\%22itemid\%22:[\%22001-99854\%22]]

5. Case of Filyutkin v. Russia (Application № 39234/08). 24.07.2018. https://hudoc.echr.coe.int/eng\#\{\%22itemid\%22:[\%22001-184813\%22]\}

6. Case of Vaneyev v. Russia (Application № 78168/13). 27.08.2019 URL: https://hudoc.echr.coe.int/eng\#\{\%22itemid\%22:[\%22001-195570\%22]\}

7. Laudan, L. (2003). Is Reasonable Doubt Reasonable? Legal Theory. 9 (4), 295-331.

8. Postanova Verkhovnoho Sudu. 02.12.2020. № 2-5229/09. URL: https://reyestr.court.gov.ua/Review/93438176 (in Ukrainian)

9. Case of Salov v. Ukraine (Application № 65518/01). 06.09.2005. https://hudoc.echr.coe.int/eng\#\{\%22fulltext $\% 22:[\% 22$ Salov\%20v.\%20Ukraine $\% 22], \% 22$ documentcollectionid2\%22:[\%22GRANDCHAMBER\%22,\%22CH AMBER\%22],\%22itemid\%22:[\%22001-70096\%22]

10. Komentari do Banhalorskykh pryntsypiv povedinky suddiv, Upravlinnia OON z narkotykiv ta zlochynnosti. (2007). http://rsu.gov.ua/ uploads/article/komentari-bangalorski-9818bfbb11.pdf (in Ukrainian).

11. Case of Paskal v. Ukraine (Application № 24652/04). 15.09.2011. https://hudoc.echr.coe.int/eng\#\{\%22fulltext\%22:[\%22Paskal\%20v.\%20Ukrai ne $\% 22$ ],\%22documentcollectionid2\%22:[\%22GRANDCHAMBER\%22,\%22C HAMBER\%22],\%22itemid\%22:[\%22001-106169\%22]]

12. Case of Bulut v. Austria (Application № 17358/90). 22.02.1996. https://hudoc.echr.coe.int/eng\#\{\%22fulltext\%22:[\%22BULUT\%20v.\%20AUS TRIA\%22], \%22documentcollectionid2\%22:[\%22GRANDCHAMBER\%22,\%2 2CHAMBER\%22],\%22itemid\%22:[\%22001-57971\%22]\}

13. Banhalorski pryntsypy povedinky suddiv. (2006). https://zakon.rada.gov.ua/ laws/show/995 j67\#Text (in Ukrainian).

14. Kodeks suddivskoi etyky, XI cherhovyi z'izd suddiv Ukrainy. (2013). https://zakon.rada.gov.ua/rada/show/n0001415-13\#Text (in Ukrainian).

15. Radutnaia, N.V. (2002) Эtyka sudy. M.: Rossyiskaia akademyia pravosudyia (in Russian).

16. Fiss, O.M. (1991). Reason in All Its Splendor. Brooklyn Law Review, 56.

17. Tersman, F. (2012). Intuitional Disagreement. The Southern Journal of Philosophy. 50

18. Zakon Ukrainy "Pro sudoustrii i status suddiv". Naukovo-praktychnyi komentar (2019) / za zah. red. M.A. Pohoretskoho, O.Z. Khotynskoi-Nor, O.H. Yanovskoi. Kyiv: Alerta, (in Ukrainian).

19. Case of Agrokompleks v. Ukraine (Application № 23465/03). 25.07.2013. https://hudoc.echr.coe.int/eng\#\{\%22fulltext\%22:[\%22Agrokompleks \%20v.\%20Ukraine \%22],\%22documentcollectionid2\%22:[\%22GRANDCHAM BER\%22,\%22CHAMBER\%22],\%22itemid\%22:[\%22001-207964\%22]\}

20. Case of Paunovic v. Serbia (Application № 54574/07). 03.12.2019. https://hudoc.echr.coe.int/eng\#\{\%22itemid\%22:[\%22001-198991\%22]\}

21. Case of Romanova v. Ukraine (Application № 33089/02). 13.12.2007. https://hudoc.echr.coe.int/eng\#\{\%22fulltext\%22:[\%22Romanova \%20v.\%20Ukraine\%22],\%22documentcollectionid2\%22:[\%22GRANDCHAM BER\%22,\%22CHAMBER\%22],\%22itemid\%22:[\%22001-83969\%22]\}

22. Case of Farhi v. France (Application № 17070/05). 16.01.2007. https://hudoc.echr.coe.int/eng\#\{\%22fulltext\%22:[\%22Farhi\%22],\%22docum entcollectionid2\%22:[\%22GRANDCHAMBER\%22,\%22CHAMBER\%22], \% 22itemid\%22:[\%22001-79047\%22]\}

O. Khotynska-Nor, Dr. Sc. (Law), Prof.

Taras Shevchenko National University of Kyiv, Kyiv, Ukraine

\section{"IMPARTIALITY OF THE COURT" AS A STANDARD OF FAIR JUSTICE: ECHR CASE LAW AND PROSPECTS OF DEVELOPMENT IN UKRAINE}

The article examines the content and nature of such established standard of fair justice as impartiality of the court. The latter is widely interpreted in case law of the European Court of Human Rights. Based on a systematic analysis of the array of ECHR judgments, a number of significant positions, characterizing the standard of impartiality of the court, have been identified. These include: 1) impartiality of the court is in dichotomous interrelation with the category of "partiality"; 2) the impartiality of the court is assessed by two criteria: (a) subjective, which is in a plane of the judge's personality and beliefs; (b) objective, which is in a plane of existing safeguards and mechanisms to be used by the court to avoid reasonable doubt about partiality and accusations of being partial; 3) determining influence of the external manifestation of impartiality of the court; 4) expedient reasonability of doubts about impartiality; 5) diversity and unlimited range of situations that may cast doubt on the impartiality of the court.

Given that the ECHR assesses impartiality of a national court on the basis of subjective and objective criteria, it has been given special attention and the specifics of its application have been determined. In the process of analysis, it has been concluded that emergence of such criteria is due to the complex ethical and legal nature of the studied standard. It is substantiated that the standard of impartiality of the court has its roots in the moral basis of the judicial profession, which has evolved and transformed into a system of rules of professional conduct and legislation targeted at achieving the objectives of justice and realization of the right to a fair trial. The ethical nature of the impartiality of the court determines assessment of compliance with this standard on a subjective basis. At the same time, its legal nature, which covers the institutional and procedural components, promotes development of the relevant guarantees in the national law, existence of which is a criterion for assessing impartiality of the court by an objective criterion. In the context of the latter thesis, the special importance of the institution of recusal of a judge as a procedural guarantee of the impartiality of the court is emphasized. It is argued that in national civil, commercial and administrative proceedings, as well as the rules and procedures for disqualifying a judge need to be improved in the direction of implementing the postulate "no one can be a judge in his own case."

Keywords: impartiality of the court, independence of the court, fair justice, right to a fair trial, criteria for assessing the impartiality of the court, standards of justice 